\title{
Szkolna narracja o uchodźcach a formacyjny wymiar edukacji polonistycznej
}

\section{School narration on refugees and the formative dimension of Polish language education}

\author{
$\| \begin{aligned} & \text { Krzysztof Koc } \\ & \text { Uniwersytet im. Adama Mickiewicza w Poznaniu }\end{aligned}$
}

\begin{abstract}
The basic thesis of the article is the conviction that the condition for an effective implementation of the formative function of humanistic education is reflection on the contemporary world, and especially on such disturbing and current problems as, for example, intercultural tensions, migrations and connected with them the refugee crisis. The analysis of texts addressing this topic in the Polish school may be a response to the ethical crisis of isolation from other people's suffering and passivity towards evil, especially if the victims are people belonging to a different cultural or national community. Inspiration for such considerations can be found in reportages devoted to refugees and their situation.
\end{abstract}

Keywords: education, refugees, reportage, ethics, Europeanness

Streszczenie: Podstawową tezą artykułu jest przekonanie, że warunkiem skutecznego realizowania formacyjnej funkcji edukacji humanistycznej jest refleksja nad współczesnym światem, a szczególnie nad tak niepokojącymi i aktualnymi problemami, jak np. napięcia międzykulturowe, migracje i związany z nimi kryzys uchodźczy. Analiza w polskiej szkole tekstów podejmujących tę tematykę może być odpowiedzią na kryzys etyczny polegający na izolowaniu się od cudzego cierpienia i na bierności wobec zła, zwłaszcza jeśli ofiarami są ludzie należący do innej niż nasza wspólnoty kulturowej czy narodowej. Inspirację do takich rozważań można odnaleźć w reportażach poświęconych uchodźcom i ich sytuacji.

Słowa kluczowe: edukacja, uchodźcy, reportaż, etyka, europejskość

\section{Niełatwe pytania}

Refleksja nad tym, czy powinno się na lekcjach języka polskiego w szkole poruszać trudną problematykę dotyczącą uchodźców, nie sprowadza się do rozważenia jeszcze jednego zagadnienia, które można by wkomponować w cykl zajęć z młodymi ludźmi. Dotyka ono samego sedna edukacji, nie tylko polonistycznej, ale i humanistycznej. Skłania do zastanowienia się 
nad sensem formacyjnej funkcji nauczania, warunkami jej realizacji, przyświecającym jej założeniom.

George Steiner, opisując powojenną rzeczywistość kulturową i etyczną naznaczoną dramatem Holokaustu, przedstawił jej diagnozę, która z perspektywy współczesności okazuje się zaskakująco i niepokojąco aktualna:

Znowu uwikłani jesteśmy w politykę tortur i zakładników. (...) Nasz próg wrażliwości przerażająco się obniżył. Kiedy z Polski przemycono pierwsze raporty na temat obozów śmierci, najczęściej przyjmowano je z niedowierzaniem; takie rzeczy nie mogły mieć miejsca w cywilizowanej Europie, w połowie XX wieku. Dzisiaj trudno byłoby wymyślić torturę, szaleństwo prześladowań czy nagłego zniszczenia, które nie byłyby wiarygodne, które szybko nie wpisywałyby się w porządek faktów. Brak zaskoczenia jest czymś moralnie, psychologicznie, strasznym. W nieunikniony sposób nowy realizm konspiruje z tym, co jest, czy powinno być, najmniej akceptowane w naszej rzeczywistości.

Ponadto nie wykazujemy tendencji, by uważać obecny klimat ekstremalności za chwilowe obsunięcie się, zły okres, który wkrótce zostawimy za sobą. I to jest element decydujący (Steiner 1993, 79).

Namysł nad aksjologicznym wymiarem kształcenia, ze względu na to, że dotyczy przede wszystkim młodych ludzi, wymaga w pierwszej kolejności rozpoznania rzeczywistości kulturowej, społecznej, a nawet geopolitycznej, w której ma być realizowany i w której ci młodzi żyją. Jednym z wyzwań jest opisane przez Steinera dramatyczne zmniejszenie wrażliwości na cierpienie, przemoc, i wprost proporcjonalne zwiększenie poziomu przynajmniej milczącej akceptacji, a na pewno obojętności wobec różnych form okrucieństwa oraz ich skutków. Przykłady to potwierdzające i do tego aktualne łatwo wskazać w dyskursie publicznym (politycznym), w którym język wykluczenia, uproszczeń, zaskakujących uogólnień, a nawet nienawiści i ksenofobii sprawia, że trudne i skomplikowane zagadnienia - problem uchodźców, terroryzmu i wojen - wykorzystuje się do bieżącej walki politycznej, zmuszając uczestników tej debaty do zajęcia jednoznacznych, często ostro wartościowanych stanowisk i przejmowania schematów w ten język wpisanych. Symptomy wspomnianego kryzysu etycznego są też widoczne w szkole i to w obszarze szczególnie ważnym dla szkolnej polonistyki, bo dotyczącym stosunku uczniów do literatury modelowanego przez sposób jej analizowania i interpretowania. Tak opisuje tę kwestię Krystyna Koziołek:

W zasadniczej części, teksty czytane w szkole, to lektura zła. (...) Nie mam na myśli jedynie tematycznej i moralnej treści lektur kanonicznych, ale bardziej jeszcze wzorcowe odczytania, które koncentrują się na ciemnej stronie literatury; eksponują zło, upadek, kryzys, katastrofę, zagładę etc. jako zagadnienia szczególnie wskazane do komentowania na lekcji.

Tymczasem podmiotem takiej lektury jest bardzo młody człowiek, który nawet rozumiejąc ukazane tam problemy, nie ma prawa moralnego do przejęcia większości z nich oraz do wypełnienia ich - za sprawą wyobraźni - uczuciem i myślą (Koziołek 2017, 92). 
Literatura, także ta omawiana w szkole, zawiera oczywiście „potencjał etyczny" - diagnozuje kryzysy wartości, rozchwianie ich hierarchii, przybliża dylematy oraz wątpliwości moralne, skłania do refleksji nad istotą zła i dobra, odsłania często niejednoznaczne między nimi relacje, pokazuje to, co w człowieku szlachetne, godne podziwu, ale znacznie częściej to, co w naturze ludzkiej jest przerażające (okrucieństwo, nienawiść, egoizm, konformizm itd.). Warto jednak zadać sobie niewygodne pytanie: Jak to się dzieje, że analiza i interpretacja dzieł np. Orwella, Dostojewskiego, Camusa, Borowskiego, Herlinga-Grudzińskiego, Herberta, Miłosza, Szymborskiej, Mickiewicza, Szekspira, Moliera, Sofoklesa, wybranych tekstów biblijnych i mitologicznych i wielu innych podejmujących fundamentalne kwestie etyczne, nie zapobiega obniżeniu progu wrażliwości na cudze cierpienie (zwłaszcza jeśli nie dotyczy ono naszej wspólnoty lokalnej czy narodowej) i zło, nie uodparnia ani na język agresji, pogardy i nienawiści, ani na przemoc? Krystyna Koziołek widzi w tym problem znacznie szerszy i wiąże go z samą istotą kształcenia literacko-kulturowego i sposobem jego urzeczywistniania w szkolnej praktyce:

Mam na myśli zadziwiającą niewiarę w siłę przekazu sztuki, jakbyśmy, wbrew sile czytanych słów i oglądanych obrazów, ciągle nie wierzyli w literaturę i jej nauczanie jako eksperymenty estetyczne, etyczne i egzystencjalne niezwykle wpływowe dla kształtowania osobowości ucznia w szkole. Wpływowe dla jego dobra i zła zarazem. (...) W zadziwiający sposób zniknął z rzeczywistości szkolnej lęk przed wpływem literatury i jej komentowania, jakby szkoła impregnowała umysły uczniów na działanie zmasowanego przekazu negatywnego, jaki niosą szkolne teksty. Ogromna część zawartości lektur to świadectwa tyleż wielkości, co nędzy ludzkiej kondycji (Koziołek 2017, 91).

Ta diagnoza wywołuje kolejne wątpliwości. Czy przypadkiem nie jest tak, że na kryzys etyczny, o jakim wspomniał Steiner, nie nakłada się kłopot związany zarówno z koncepcją odczytywania tekstów kultury funkcjonujących w szkolnym obiegu, a wraz z nim trudność związana z realizacją formacyjnej funkcji edukacji polonistycznej (czy szerzej - humanistycznej)? Czy możliwe, że istnieje związek między obojętnością na zło i cierpienie a sceptycyzmem, z jakim w szkole podchodzi się do wychowawczych i aksjologicznych wymiarów kształcenia literackiego i językowego? Czy to, że uczniowie często literaturę opisującą „nędzę ludzkiej kondycji” poznają za pośrednictwem streszczeń albo z relacji kolegów i koleżanek i nie odczuwają potrzeby ich czytania w całości lub we fragmentach, o czym cyklicznie przypominają choćby raporty o stanie czytelnictwa publikowane przez Bibliotekę Narodową, nie jest świadectwem nie tylko kulturowego oraz społecznego, ale i metodycznego kryzysu? Czy uczniowie nie czytają tych często bardzo dramatycznych, tragicznych, nierzadko prowokacyjnych opowieści przedstawiających dość przygnębiającą wizję ludzkiego losu, bo ich to nie interesuje, czy dlatego, że nie poruszane $\mathrm{w}$ nich problemy są na lekcjach w centrum uwagi, tylko ich cechy gatunkowe, kompozycja, 
związek z epoką, prądem literackim, występujące środki artystycznego wyrazu, konstrukcje językowe, pojęcia literackie itd. (czyli w zasadzie ciągle to samo i tak samo...)?

\section{Czytać? Tylko po co?}

Uważnej, pogłębionej i wielowymiarowej refleksji nad podstawowymi kwestiami etycznymi podejmowanymi w dziełach analizowanych w szkole nie sprzyjają również zmiany kulturowe, a szczególnie ekspansja mediów cyfrowych, dostarczających uczniom znacznie intensywniejszych doznań i rozrywek niż lektura. Dynamika tych zmian może prowadzić w dwóch kierunkach. Jeden polega na utrwaleniu i wzmocnieniu „parauniwersyteckiego", steoretyzowanego, strukturalnego, często historycznoliterackiego sposobu obcowania z literaturą w szkole jako formą ucieczki od otaczającej ucznia rzeczywistości kulturowej oraz jako próby zbudowania rzeczywistości alternatywnej, osadzonej w dość jednoznacznie określonej i zinterpretowanej tradycji narodowej, a więc w przeszłości zamykającej współczesności dostęp do siebie. Analizę strukturalną utworu i koncepcję jego interpretacji polegającą na transferze do szkoły uniwersyteckiego, filologicznego sposobu czytania wraz z preferowaniem w edukacji powszechnej przede wszystkim kompetencji dotyczących „oprzyrządowania teoretyczno-metodycznego" (Koziołek 2017, 89) jednak nawet intuicyjnie trudno uznać za właściwą drogę prowadzącą zarówno do zwiększenia poziomu czytelnictwa wśród młodzieży, jak i do celu aksjologicznego, jakim jest kształtowanie własnej tożsamości.

Drugi kierunek to uznanie znaczenia literatury i aktu lekturowego jako jednego z wielu możliwych i aktualnie dostępnych sposobów uczestnictwa w kulturze, który może być dla człowieka, zwłaszcza młodego, ważny, potrzebny i atrakcyjny. Aby to jednak było możliwe, konieczna jest rezygnacja z wiedzy o literaturze jako nadrzędnym celu edukacji polonistycznej i zastąpienie go egzystencjalnym sposobem rozumienia jej roli. Takie ujęcie okazuje się, jak potwierdza przykład Szwecji, podstawą działań sprzyjających podnoszeniu kultury i poziomu czytelnictwa, także wśród młodych. W książce Szwecja czyta. Polska czyta Stefan Ingvarsson, szef programowy festiwalu literackiego Stockholm Literature, tak określa rolę literatury:

Literatura jest naszą współczesną mitologią, opowieścią o nas samych, o innych, i trudno jest wyczuć, jakiej historii w danym momencie potrzebuje zbiorowość (Szwecja czyta. Polska czyta 2015, 23).

W podobny sposób, ale z nieco innej perspektywy ujmuje to Ingemar Fasth, szef literacki sztokholmskiego Kulturhuset-Stadsteatern:

Bardzo szybko literatura stała się dla mnie niesłychanie ważna, była czymś dużo więcej niż przyjemnością, czymś konstytuującym. To w książkach znajdowałem odpowiedzi na nurtujące mnie pytania. Książka od zawsze była dla mnie partnerem 
do rozmowy i drogowskazem. Brzmi to może trochę podręcznikowo, ale potrzebuję literatury, by zrozumieć siebie i świat (Szwecja czyta. Polska czyta 2015, 33).

W cytowanych wypowiedziach, jak również w przywołanej już książce Krystyny Koziołek, przekonanie o wartości literatury dla pojedynczego człowieka i dla zbiorowości wynika z tego, że stawia pytania i formułuje odpowiedzi ważne tu i teraz. Nie ucieka zatem przed współczesnością w przeszłość, ale jest sposobem dialogu z człowiekiem i zbiorowością na temat tego, co ważne, niepokojące, przerażające, cenne, oczekiwane itp. Jednym z takich tematów jest stosunek do innego, obcego, przybysza, emigranta, uchodźcy, a więc i kwestie związane z etyką (wartościami, postawami i ich konsekwencjami, moralnymi dylematami), jakże istotne dla rozumienia tego, co się dzieje we współczesnym świecie i wokół nas.

\section{Formacyjny wymiar edukacji - między teorią a praktyką}

Zarysowane powyżej spojrzenie na istotę i funkcję literatury nie jest dla uniwersyteckiej dydaktyki polonistycznej czymś nowym i zaskakującym, ale bardzo interesującą częścią jej dorobku, poświęconą właśnie formacyjnemu wymiarowi edukacji polonistycznej w szkole. Tym bardziej powinno się zadbać o to, by koncepcje dotyczące realizacji tego wymiaru stały się elementem szkolnej praktyki. Wówczas też pytanie o celowość wprowadzania na lekcje języka polskiego tekstów na temat uchodźców należałoby rozszerzyć na pytania, jak to robić i w jakim celu.

Zenon Uryga, na długo przed przywołaną już książką Koziołek, charakteryzując wymiary przedmiotu język polski, wyodrębnił wśród nich wymiar społeczno-filozoficzny i tak opisywał jego edukacyjny potencjał (odwołując się z kolei do ustaleń Marii Kwiatkowskiej-Ratajczak zawartych w jej pracy pt. Z perspektywy wartości o prozie dla dzieci i młodziė̇y, Poznań 1994):

Szkoła stoi obecnie przed koniecznością przywrócenia językowi polskiemu rangi przedmiotu odpowiedzialnego za poznawanie człowieka w jego psychologicznym i społecznym, a także filozoficznym wymiarze. Ów wymiar ostatni wyznacza przedmiotowi szczególne zadania formacyjne.

Poznawanie literatury w szkole otwiera drogę do refleksji moralnej, związanej z oceną czynów człowieka, oraz do stopniowego rozpoznawania norm etycznych regulujących jego społeczne zachowania. Pozwala też wrastać w uniwersum wartości, w których człowiek się realizuje, akceptując jedne z nich, odrzucając inne. Literatura odsłania sferę poglądów człowieka na hierarchię wartości lub wpisuje tę hierarchię w konstrukcję swoich światów (Uryga 1996, 25).

Krakowski badacz miał na myśli zerwanie z ideologicznym wykorzystywaniem tekstów literackich oraz z dydaktyzmem sprowadzającym się do skonwencjonalizowanych charakterystyk postaci oraz formułowania normatywnych wzorców postępowania. Postulat okazuje się jednak zaskakująco aktualny wobec wspomnianego wcześniej procesu „unaukowienia” kształcenia literacko-kulturowego, jak i wobec potrzeby uczenia młodych ludzi rozumienia współczesności. Odzyskanie przez koncepcję kształcenia 
literackiego w szkole egzystencjalnych i aksjologicznych podstaw wydaje się jedyną możliwością realizowania przez polonistów formacyjnych zadań; pozwala też lepiej zapobiegać indoktrynacji, ideologizacji oraz instrumentalnemu traktowaniu tekstów. Refleksja nad dramatem uchodźców ujęta w takie ramy może i powinna być namysłem nad charakterem norm etycznych i relacjami społecznymi, nad znaczeniem takich wartości, jak np. wolność, solidarność, odpowiedzialność, bezpieczeństwo, rodzina, dom, ojczyzna, religia, europejskość, a także nad konfliktami i napięciami wynikającymi ze spotkania z innym. W żadnym razie natomiast nie należy jej wykorzystywać do uzasadnienia wyższości jednych racji politycznych nad innymi czy jako głosu w bieżącej dyskusji nad trafnością lub nietrafnością decyzji stojących za szczegółowymi rozwiązaniami prawnymi odnoszącymi się do uchodźców oraz migracji.

Formacyjne zadania przedmiotu język polski są eksponowane szczególnie $\mathrm{w}$ antropologiczno-kulturowym nurcie myślenia o dydaktyce polonistycznej, gdzie określają ramy, kierunki i cele procesu kształcenia. Zofia Agnieszka Kłakówna, charakteryzując koncepcję przedmiotu z tej właśnie perspektywy, zwraca uwagę, jak ważne jest jej dostosowanie do jasno określonej filozofii człowieka. Ponieważ z punktu widzenia badaczki największymi wyzwaniami wymagającymi edukacyjnej troski są: problem relacji między ludźmi oraz między człowiekiem i światem, poszukiwanie uzasadnienia dla dokonywanych wyborów moralnych w sytuacji rozchwiania systemu wartości i wobec kryzysu etycznego, o czym była już mowa, potrzeba odnalezienia trwałych podstaw ludzkiej egzystencji i jej sensu, budowanie więzi między jednostką a zbiorowością oraz między współczesnością a przeszłością, proponuje zakorzenienie koncepcji przedmiotu język polski w „filozofii dramatu”, której patronuje Józef Tischner:

Człowiek - powtarzamy za Józefem Tischnerem - jest „istotą dramatyczną”, a to znaczy, że działa w przestrzeni, która stanowi scenę jego istnienia i aktywności, pozostaje w stosunku do tej sceny w jakichś relacjach, pozostaje także w relacji do czasu (także Historii) oraz wchodzi w relacje z innymi. Rozpięty między dobrem i złem pyta o sens swego istnienia, dociekając istoty swej ludzkiej kondycji.

Inaczej mówiąc, pytania o istotę, sposób lub przyczynę istnienia czegoś lub kogoś, więc pytania o sens, zręczniej lub mniej zręcznie, precyzyjnie lub mniej precyzyjnie formułowane albo tylko dające o sobie znać na poziomie podświadomych niepokojów, w pewnych sytuacjach zdają się zaprzątać każdego. Także całkiem małe dzieci, także dzieci i młodzież w wieku szkolnym (Kłakówna 2016, 97-98).

Warto zauważyć, jak wielką rangę w tak rozumianej formacyjnej funkcji kształcenia polonistycznego pełnią pytania. One bowiem pozwalają dostrzec uniwersalność odwiecznych ludzkich wątpliwości, także tych dotyczących kwestii etycznych. Edukacja sprowadzona do przekazywania uczniom wyłącznie odpowiedzi, i to w formie gotowych wykładni sensów, które należy zapamiętać i odtworzyć, jak i edukacja ukierunkowana na przekazywanie wiedzy o literaturze ignorują owe pytania lub bagatelizują ich 
znaczenie. Trudno zatem od takich sposobów myślenia o celu kształcenia polonistycznego (humanistycznego) oczekiwać, by uwzględniały formacyjny jego wymiar nie tylko w deklaracjach i określaniu szkolnych powinności.

Kłakówna - za Tischnerem - wskazuje, że „podstawowe”, egzystencjalne rozterki wynikają z doświadczenia spotkania z innymi ludźmi, które jest nieprzewidywalne, stanowi często etyczne wyzwanie, skłania do przyjęcia bardzo różnych postaw ${ }^{1}$, zmusza do refleksji o tym, co ludzi łączy i dzieli. Wydaje się, że współczesna zglobalizowana rzeczywistość zwielokrotnia skalę tego problemu, a jednocześnie potwierdza znaczenie tychże rozterek. Zadaniem edukacyjnym jest więc ukazanie kulturowej ciągłości, stałego kodu składającego się z pytań, świadczących o potrzebie zrozumienia siebie, innych i świata oraz różnorodnych kulturowych odpowiedzi, które nierzadko pozostają świadectwem egzystencjalnych wątpliwości.

\section{Opowieści o uchodźcach jako opowieści o człowieku}

Analiza na lekcjach języka polskiego opowieści o dramatycznych losach uchodźców pozwala wkomponować je w rozważania o naturze człowieka, o wartościach, o dramacie ludzkiej egzystencji, o dobru i złu, o postawach wobec cierpienia. Kwestie te, podejmowane w literaturze pięknej, mogą w ten sposób przejrzeć się w literaturze niefikcjonalnej i odwrotnie, potwierdzając egzystencjalną wartość lektury i znosząc barierę między tym, co prawdopodobne, wykreowane, wyobrażone i wymyślone, a tym, co rzeczywiste, potwierdzone obserwacją i uczestnictwem, zrelacjonowane przez konkretnych ludzi i udokumentowane, a także między tradycją literacko-kulturową a aktualną rzeczywistością społeczną, polityczną czy gospodarczą.

Czytanie w perspektywie egzystencjalnej i aksjologicznej - znamienne dla antropologiczno-kulturowej koncepcji przedmiotu oraz tak ważne dla sposobu lektury i interpretacji wielkich kulturowych opowieści - z powodzeniem może być też kluczem otwierającym rozumienie na przykład tekstów reporterskich o losach ludzi zmuszonych do opuszczenia swoich domów i ojczystych stron w wyniku wojen, prześladowań czy biedy. Utrata domu, rodziny, wygnanie, poczucie wykorzenienia, motyw wędrówki, tułaczki, podróży, samotność, doświadczanie bólu i odrzucenia, ucieczka to przecież tematy poruszane na lekcjach języka polskiego w związku z analizą wielu „kanonicznych” utworów. Otwierają one możliwość refleksji nad ponadczasowością tych dramatycznych doświadczeń wpisanych w ludzką kondycję, a także skłaniają do stawiania trudnych pytań o prawo do wolności, o sens cierpienia, o relacje między dobrem i złem, o granice solidarności i poświęcenia dla innych, o związki między sprawiedliwością a miłosierdziem, o powinności etyczne wobec drugiego człowieka, a także o tożsamość i relacje między jednostką a zbiorowością. Umieszczenie

${ }^{1}$ Temat ten poruszał w swoich wykładach Ryszard Kapuściński. Warto je wprowadzić na lekcje języka polskiego jako kontekst wspomagający refleksję nad filozoficznym i kulturowym znaczenie spotkania z innym. Zob. Kapuściński Ryszard, 2006, Ten Inny, Kraków. 
w tym kręgu rozważań problematyki dotyczącej uchodźców uniwersalizuje ją; sprawia, że trudno uznać ją za taką, która nas, Europejczyków, Polaków nie dotyczy i nie obchodzi.

\section{Opowieści o uchodźcach jako pytania o europejską tożsamość}

Warto zauważyć, jak znaczącą wagę przywiązuje się w edukacji polonistycznej do rozpoznawania źródeł kultury europejskiej oraz prób zdefiniowania istoty europejskiej tożsamości. Metafora drzewa zakorzenionego w kulturze judeochrześcijańskiej, greckiej i rzymskiej w różnych wariantach jest konstytutywnym jej elementem; Ateny, Rzym, Jerozolima to trzy punkty na mapie, które określają ramy kultury śródziemnomorskiej, a ta jest przedmiotem chluby i dumy Europejczyków oraz trwałym punktem odniesienia przy określaniu przez nich wartości najbardziej cenionych. Kapitalnie wyjaśnia znaczenie tego dziedzictwa Andrzej Bobkowski w Szkicach piórkiem, porównując je do trzech wpłat do karcianego banku. Podkreśla jednak kontrast jakościowy między wpłatą grecko-rzymską a chrześcijańską. O dziedzictwie grecko-rzymskim pisał tak:

To były wpłaty grecka, rzymska i chrześcijańska. Ale każda z tych wpłat, równa co do wartości, rzucona była w innej walucie. (...) Grecy wpłacili pojęcie człowieka i rozum, zwyczajny ludzki rozum, jako miarę wszystkiego. (...) Dzięki temu stworzyli teorię. (...). Rzymianie wpłacili praktykę, a w niej głównie prawo i naukę o jego poszanowaniu. (...) Grecy i Rzymianie wpłacili swoje stawki poniżej zera. Panował mróz. To wszystko było zimne pomimo usiłowań wielkich filozofów, którzy czuli ten chłód, ale nie potrafili z niego wyjść i nie potrafili ogrzać temperatury świata, bo brakło im - pomimo wszystko - poczucia człowieczeństwa. Człowiek był dla nich myślącą bryłą mięsa (Bobkowski 2003, 58).

$\mathrm{Na}$ tym tle eksponuje wyjątkowość chrześcijaństwa jako wyróżniającego elementu europejskiej tożsamości:

I nagle w tym miejscu, w którym na termometrze jest czerwona kreska, rodzi się Chrystus. Temperatura od razu wzrasta, bo z jego narodzeniem rodzi się dopiero prawdziwy człowiek. On i jego uczniowie niosą słowo o nowym człowieku, o jego życiu doczesnym i o życiu duszy, o wieczności. Dopiero w tym człowieku krąży naprawdę ciepła krew (...). Dopiero ten człowiek zaczyna mieć prawdziwe poczucie godności ludzkiej (Bobkowski 2003, 58).

O ile istnieje edukacyjna zgoda ponad koncepcyjnymi i metodycznymi różnicami, że tak właśnie kształtowała się europejska samoświadomość i dlatego należy tę tradycję uczniom przybliżać i objaśniać, o tyle można mieć wątpliwości, w jakim stopniu przekonaniu temu towarzyszy poczucie etycznej powinności, by wartości stojące za tym dziedzictwem zostały przez młodych ludzi przyswojone, by stały się aksjologicznym filtrem wpływającym na sposób postrzegania otaczającego ich świata i ludzi. Trudno bowiem mówić o realizowaniu formacyjnej funkcji na lekcjach polskiego, jeśli wprowadzanie uczniów $\mathrm{w}$ obszar kultury śródziemnomorskiej ma polegać na odtworzeniu przez nich treści im przekazywanych czy to przez 
nauczyciela, czy to za pośrednictwem podręcznika, a dotyczących tematyki poszczególnych utworów, wiedzy o gatunkach, filozofii, sztuce itp. Bożena Chrząstowska zwracała uwagę, że wprowadzanie problematyki aksjologicznej jest zadaniem o wiele bardziej skomplikowanym niż transmitowanie przekazu zawierającego nawet najlepiej objaśnione sensy; wiąże się ściśle m.in. z wychowawczymi powinnościami integralnie związanymi z przedmiotem język polski:

kształcenie polonistyczne w szczególny sposób powinno służyć wychowaniu ku wartościom, tzn. budowaniu przez ucznia własnej hierarchii wartości i odpowiadaniu na wezwanie wartości - aprobatą dobra, negacją zła (Chrząstowska 2009, 145).

Wprowadzenie na lekcje języka polskiego tekstów o uchodźcach nie może być publicystycznym wtrętem sztucznie aktualizującym rozpoznania poczynione podczas analizy i interpretacji dzieł literackich omawianych w szkole. Warto je wkomponować w projekt edukacji humanistycznej jako inspirację do rozważań poświęconych tożsamości europejskiej i żywotności wartości, z których ona wyrasta. Nie chodzi jednak o oddziaływanie na emocje kosztem intelektualizacji problemu - takiej dezintegracji w procesie odbioru tekstów jako barierze utrudniającej realizowanie wychowawczych powinności sprzeciwiała się choćby wspomniana już Chrząstowska:

W tradycji polskiej dydaktyki ciągle przeciwstawia się kształtowanie wrażliwości i emocjonalnego przeżycia odbioru rozwijaniu sprawności intelektualnych (co można by nazwać trwałym zabobonem szkolnej polonistyki) (Chrząstowska 2009, 149).

W odpowiedzi na ową dychotomię autorka Lektury i poetyki domagała się integracji kształcenia literacko-kulturowego i językowego z powinnościami wychowawczymi:

Wychowanie na lekcjach języka polskiego nie jest - i nie powinno być - czymś osobnym, musi ono wynikać w sposób naturalny z refleksji nad literaturą, kulturą czy językiem (Chrząstowska 2009, 148).

Te przecież wcale nie nowe podstawy realizowania formacyjnych zadań w szkolnej polonistyce, funkcjonujące w dyskursie naukowym², warto przypomnieć i przełożyć na rozwiązania praktyczne, w tym te odnoszące się do

2 Sposób myślenia Chrząstowskiej polegający na integralnym traktowaniu kwestii dotyczących kształcenia literacko-kulturowego, językowego i wychowawczego w ramach przedmiotu język polski odnaleźć można w wielu innych pracach z końca XX wieku (artykuł Chrząstowskiej, z którego przywołano cytaty, ukazał się w 1999 roku) i początku XXI w. Pisała o tym np. Maria Kwiatkowska-Ratajczak w książce Z perspektyw wartości o prozie dla dzieci i młodzieży (Poznań 1994), Maria Jędrychowska w Najpierw człowiek. Szkolna edukacja kulturowo-literacka a problem kształcenia dydaktycznego polonistów. Refleksja teleologiczna (Kraków 1996), Zofia Agnieszka Kłakówna w Przymus i wolność. Projektowanie procesu kształcenia kulturowej kompetencji (Kraków 2003), Wiesława Wantuch w Aspekty integracji w nauczaniu języka polskiego (Kraków 2005), Barbara Myrdzik w Zrozumieć siebie i świat. Szkice i studia o edukacji polonistycznej (Lublin 2006). Por. też: Barbara Myrdzik, Recepcja poezji Zbigniewa Herberta (Lublin 1992); Tadeusz Patrzałek, Dydaktyka mówienia o wartościach i ocenach, „Polonistyka” 1996, nr 4. Związkom między kształceniem literacko-kulturowym i formacyjnymi zadaniami kształcenia polonistycznego w szkole poświęcone są też rozprawy metodyczne wydawane przez Universitas, np. praca Anny Janus-Sitarz Przyjemność i odpowiedzialność w lekturze (Kraków 2009) oraz tom Wartościowanie a edukacja polonistyczna pod red. Anny Janus-Sitarz (Kraków 2008). Ta lista nie jest oczywiście kompletna, ukazuje jednak, jak ważną rolę ten sposób myślenia odgrywa w refleksji poświęconej współczesnej edukacji polonistycznej, mimo różnych sposobów postrzegania jej celów i sposobu ich osiągania. 
sfery wartości ważnych dla kultury europejskiej. Przecież dziedzictwo śródziemnomorskie nie ogranicza się do mniej lub bardziej bogatego repertuaru tekstów kultury, nie tylko odnosi się do przeszłości (tradycji), ale wpływa na współczesne światoodczuwanie. Myśląc o bohaterstwie, heroizmie, poświęceniu, solidarności, odwadze, rodzinie, Bogu itd., posługujemy się pewnym kulturowo stabilnym kodem kulturowym ukształtowanym w obszarze śródziemnomorskim. Co więcej, do tego kodu odwołujemy się także wówczas, gdy opisujemy kryzys wartości, a nawet ich rozpad. Lekcje języka polskiego poświęcone problematyce uchodźców i współczesnych migracji mogą być aksjologicznie cenne choćby z tego powodu, że temat ten można ująć jako swoiste wyzwanie rzucone europejskiej tożsamości i dziedzictwu, którym się ona chwali i do którego się przyznaje. Warto w tym kontekście przywołać głos Jarosława Mikołajewskiego, proponującego spojrzeć na dziedzictwo chrześcijańskie właśnie z takiej perspektywy:

Kościół, który czci Najświętsze Ciało i Krew Chrystusa, siłą rzeczy nazywa się Chrystusowym. A Chrystus powiedział: „Byłem głodny, a daliście Mi jeść; byłem spragniony, a daliście Mi pić; byłem przybyszem, a przyjęliście Mnie”. Wspomniał też o nagich, chorych i uwięzionych. I wyjaśnił: „Wszystko, co uczyniliście jednemu z tych braci moich najmniejszych, Mnieście uczynili”. I zapowiedział, że ci, którzy nie nakarmili, nie ubrali, nie przyjęli, pójdą „w ogień wieczny”.

W piekło nie wierzę, mam go po dziurki w nosie już tutaj, na ziemi. Nie mam pojęcia, czy wierzę w Boga. Za to wierzę w człowieka. Łatwo mi wierzyć, bo go zwyczajnie widzę: głodnego, obolałego, spragnionego. Odrzuconego przez praktykujące, lecz niewierzące państwo.

Przedmurze - ale czego? Bo przecież już nie chrześcijaństwa (Mikołajewski 2017).

Te gorzkie i prowokacyjne sformułowania, mimo że odnoszą się do aktualnej debaty politycznej, są ważne dla zrozumienia formacyjnych zadań przedmiotu język polski. Dotykają bowiem tak istotnej kwestii, jak relacja między wartościami deklarowanymi, przypisywanymi tożsamości europejskiej, a urzeczywistnianymi, stojącymi za realnymi postawami wobec tak trudnego problemu, jak napływ uchodźców do Europy. Także i w tym przypadku nie chodzi o to, by przekonać uczniów do którejś z racji w toczącym się sporze, czy Polska powinna przyjąć na swoje terytorium określoną liczbę uchodźców, ale o to, by w procesie samookreślania własnej przynależności kulturowej dostrzegali oni znaczenie fundamentalnych wyborów etycznych, rzeczywiście podejmowanych i to w określonym współczesnym kontekście.

\section{Opowieści o uchodźcach jako opowieści o spotkaniu z Innym}

Dla tożsamości europejskiej spotkanie z innym stało się czynnikiem określającym jej swoistość; o jego aksjologicznym, antropologicznym i filozoficznym znaczeniu przekonują teksty uważane za kanoniczne, bo reprezentatywne dla kultury grecko-rzymskiej i judeochrześcijańskiej. Podróże Herodota, przypowieść o miłosiernym Samarytaninie, tułaczka Odyseusza, 
wędrówka Żydów do Ziemi Obiecanej, ucieczka Świętej Rodziny do Egiptu, misyjne wyprawy świętego Pawła, ekspansja rzymskiego imperium to tylko kilka przykładów ukazujących dramatyzm tkwiący w tym spotkaniu, ale i zakorzenione w człowieku pragnienie wyjścia poza to, co znane i bezpieczne. Kultura europejska ze spotkania z Innym uczyniła część swej tożsamości; trzeba jednak pamiętać, że miało to swoje ciemne strony, takie jak $\mathrm{np}$. kolonializm, niewolnictwo, rasizm, antysemityzm, totalitaryzmy.

Nadal jednak przekonanie o znaczeniu spotkania z drugim jako podstawowym doświadczeniu egzystencjalnym organizuje nasze myślenie o świecie, człowieku i moralności. Jego ślady odnaleźć można również w edukacji - w antropologiczno-kulturowej (antropocentrycznej) koncepcji przedmiotu język polski, w idei podmiotowości ucznia i nauczyciela, w wypracowanych w obrębie tych ujęć sposobach analizowania tekstów kultury, w filozofii kształcenia odwołującej się do szeroko pojętego personalizmu.

Wydarzenie spotkania jest kategorią służącą również opisywaniu postaw etycznych, stojących za nimi sposobów myślenia o innych i o sobie, także w odniesieniu do jak najbardziej aktualnych wydarzeń. Przykładem może być antropologiczno-socjologiczna diagnoza postawiona Europejczykom przez Zygmunta Baumana w kontekście kryzysu migracyjnego:

Uchodźcy uciekający przed bestialstwem wojny i despotyzmem lub barbarzyństwem, na jakie skazuje życie w głodzie i bez perspektyw, od zarania nowoczesności pukali do cudzych drzwi. Z punktu widzenia tych, którzy stoją po drugiej stronie drzwi, ci przybysze byli zawsze - tak jak i teraz - obcymi. Budzą niepokój właśnie z powodu swojej „obcości”, która ma sprawiać, że są przerażająco nieprzewidywalni, w odróżnieniu od ludzi, z którymi zadajemy się na co dzień i po których, jak nam się wydaje, wiemy, czego się spodziewać. Z tego, co wiemy, ogromny napływ obcych może przecież unicestwić to, co sobie ceniliśmy, zaburzyć lub zniszczyć nasz kojąco swojski styl życia (...). O obcych wiemy jednak zbyt mało, żeby poprawnie zinterpretować ich postępowanie i opracować adekwatne reakcje - właściwie odgadnąć ich intencje i co mogą zrobić. A gdy nie wiemy, jak się zachować, jak postąpić w sytuacji, której sami nie zaaranżowaliśmy i która jest poza naszą kontrolą, czujemy niepokój (Bauman 2016, 14-15).

Bauman wiąże ze sobą ściśle kwestię spotkania, postawy etyczne i edukację. Warto zauważyć ten związek; uświadamia bowiem odpowiedzialność spoczywającą na nauczycielu za aksjologiczne wybory i etyczne postawy uczniów, które daleko wykraczają poza mury szkoły, gdyż decydują o ich funkcjonowaniu we współczesnym świecie. Refleksja na temat tekstów opisujących temat uchodźców nie tylko może ową wiedzę o obcych wzbogacić, ale przede wszystkim wprowadzić polskich uczniów w świat wyborów moralnych, sposób myślenia i odczuwania świata właściwy uchodźcom. Zrozumienie źródeł własnych lęków wydaje się też najskuteczniejszą receptą na ideologię i stereotypy karmiące się strachem wynikającym z ignorancji, niewiedzy czy bezmyślności (tj. braku zdolności do krytycznej, własnej refleksji) i narzucające gotowe tezy oraz jednoznaczne wartościowania. 


\section{Opowieści o uchodźcach - jak je czytać?}

Warto się zastanowić, jak czytać w szkole opowieści o uchodźcach, by lektura ta była osadzona $\mathrm{w}$ formacyjnym wymiarze edukacji polonistycznej i realizowała wyżej przedstawione założenia. Wystarczy zapoznać się z książką Katarzyny Boni i Wojciecha Tochmana pt. Kontener opowiadającą o położonych w Jordanii obozach dla uchodźców uciekających przed wojną w Syrii, aby uświadomić sobie, na jak wiele elementów trzeba zwrócić uwagę, by przynajmniej w pewnym stopniu zrozumieć opisywaną w niej rzeczywistość. Punktem wyjścia do zarysowania edukacyjnych możliwości pracy $\mathrm{z}$ tego typu tekstami można uczynić słowa jednego z rozmówców reporterskiej pary:

Wszystko, co w życiu zbudowałem, mówi starszy pan, wszystko, co własną pracą stworzyłem, przepadło w sekundę. Całe moje życie. Co robić z życiem, które nie ma sensu? (Boni, Tochman 2014, 89).

Słowa te wprowadzają od razu w sytuację graniczną, bez żadnych etapów pośrednich stawiają słuchaczy i odbiorce w samym jej centrum - ukazują świat, który się rozpadł, i pustkę, wobec której człowiek jest bezradny. Refleksja na temat takich sytuacji jest również obecna w szkolnej polonistyce. Temat ten pojawia się choćby podczas interpretacji opowiadań Borowskiego, Innego świata Herlinga-Grudzińskiego, Dżumy Alberta Camusa czy Zdążyć przed Panem Bogiem Hanny Krall. Trzeba jednak uzmysłowić sobie i uczniom, że to dramatyczne doświadczenie nie jest wyłącznie świadectwem historycznym ani ważnym problemem literackim. Jest natomiast doświadczeniem ludzi, którzy są pokazywani raz po raz na telewizyjnych ekranach, na fotografiach i filmach umieszczanych w Internecie, i o których się mówi w różnego rodzaju debatach. Tochman i Boni pokazują, jak opisana sytuacja graniczna przekłada się na sposób postrzegania świata przez spotkanych w obozach ludzi, na relacje międzyludzkie, na świat wartości, na sposób myślenia o cywilizacji zachodniej.

Punktów zaczepienia, umożliwiających odczytanie losów uchodźców w perspektywie egzystencjalnej i aksjologicznej, jest bardzo dużo. Jednym z nich jest wątek poświęcony dzieciom żyjącym w odwiedzanych obozach:

Wczesne popołudnie, a dzieci gdzie? Chłopcy powinni siedzieć w szkole, bo chodzą na popołudniową zmianę. Dziewczynki - na poranną. Targowa ulica jest pełna jednych i drugich. Pracują chłopcy: sprzedają papierosy, lepią ciasto na pity, kręcą watę cukrową, a trochę dalej, na niewielkim wzniesieniu, oddzielają piasek od drobnych kamieni. (...) Dzieci szmuglują na zewnątrz obozu przydziałowe paczki ryżu lub soczewicy. (...) Pracują i te, które mieszkają poza obozem. Co trzecie syryjskie dziecko w wieku szkolnym nie chodzi do szkoły. Co dziesiąte jest zmuszane do pracy. Piszą o tym jordańskie gazety. (...) Czy tylko co dziesiąte? Wystarczy się rozejrzeć to tu, to tam, by nabrać wątpliwości w tej sprawie (Boni, Tochman 2014, 82-83).

Reporterska para punkt po punkcie charakteryzuje świat dzieci pozbawionych dzieciństwa, przynajmniej w europejskim jego rozumieniu. Piszą 
o ich wykorzystywaniu przez dorosłych (zarówno jako taniej siły roboczej, jak i w działalności przestępczej), o ciążącej na najmłodszych odpowiedzialności za los rodzin, często wielodzietnych, ale także o handlu nastoletnimi dziewczynami:

Cały Półwysep Arabski wie, że Syryjkę można teraz tanio kupić. Wystarczy sto dolarów. (...) Niektórzy ojcowie robią więc interes. I usprawiedliwiają samych siebie: ciężkie mamy czasy, a opieka starszego mężczyzny, który nie jest uchodźcą, zapewni córce bezpieczeństwo. Córka sobie popłacze, ale kiedyś będzie wdzięczna (Boni, Tochman 2014, 75).

Tym jednak, co przeraża najbardziej, jest dziecięcy sposób doświadczania oraz postrzegania świata i ludzi ${ }^{3}$. Dzieci te nie tylko były i są naocznymi świadkami niewyobrażalnego okrucieństwa, ale są również celem ataków, a przede wszystkim słuchaczami wchłaniającymi opowieści dorosłych o aktach przemocy, często bardzo wyrafinowanych. W tych fragmentach książki świat dzieci jest ukazany jako budzący grozę, a do tego opisany za pomocą obrazowania o naturalistycznym rodowodzie:

Wojenne dzieci nie mają apetytu, milczą albo krzyczą całymi dniami, krzyczą po nocach, źle śpią, boją się robaków. Białe, ale i czarne robaki kojarzą im się z trupami, których przez wiele dni nikt nie sprzątnął z drogi (Boni, Tochman 2014, 121).

Rozchwianie aksjologicznych fundamentów, a właściwie ich rozpad ujęty został w zdaniach cechujących się chaotyczną strukturą składniową, wyliczeniami, wtrąceniami, kolokwializmami; liczne są też równoważniki zdań, co od razu nasuwa skojarzenia z Pamiętnikiem z powstania warszawskiego Mirona Białoszewskiego:

Huk, dym, bryzgająca krew, latające mózgi - codzienne tematy domowych rozmów. Oblężenie miasta, oblężenie wsi, ostrzał ziemia-ziemia, pociski gwiżdżą naokoło domu czasem już od piątej nad ranem. I gwiżdżą w głowach, dzień za dniem, noc za nocą. Dorośli wałkują to w kółko, przy kawie, przy herbacie, dzieci słuchają, spalone twarze, spalone ręce, spalone nogi, wszystko się przed oczami wyświetla jak w kinie, choć nic już się złego nie dzieje, wciąż się dzieje, psychiatrzy by powiedzieli flash-back, krzyk, jęk, lament, na kogo tym razem wypadło, kto ma już święty spokój (Boni, Tochman 2014, 122).

W tym przypadku poetyka służy opisaniu dziecięcej traumy w miejscu oddalonym od Polski o kilka tysięcy kilometrów czy kilka godzin lotu samolotem; także traumy tych, którzy pojawiają się w migawkach pokazujących łodzie wypełnione uchodźcami, wśród których jest wiele dzieci. Krzywda dziecka również jednak nie jest dla szkolnej polonistyki tematem zupełnie nowym. Przedstawia się ją jako graniczne doświadczenie egzystencjalne przyczyniające się do kryzysu wiary w Boga i w jakiekolwiek wartości

\footnotetext{
${ }^{3}$ Interesującą próbę przybliżenia tego bardzo trudnego problemu młodym polskim odbiorcom podjął Grzegorz Gortat w książce Moje cudowne dzieciństwo w Aleppo (Warszawa 2017). Warto rozważyć analizę tego utworu w szkole, właśnie w proponowanym w tym artykule kontekście. Obraz wojny i jej wpływu na dziecięce światoodczuwanie jest centralnym problemem opowieści snutej przez ośmioletnią Jasminę.
} 
definiujące istotę człowieczeństwa. Wystarczy przypomnieć lament i skargi Hioba, cierpienie i śmierć syna państwa Othonów stanowiące kluczowe wydarzenie określające postawy etyczne bohaterów Dżumy-doktora Rieux, Tarrou i ojca Paneloux, stosunek do umierania dzieci oraz oddzielania ich od matek będące prowokacyjnym świadectwem dehumanizacji w opowiadaniach Borowskiego czy gruntowną redefinicję heroizmu i bohaterstwa dokonaną przez Marka Edelmana w Zdażyć przed Panem Bogiem, który z uznaniem i zrozumieniem mówi o lekarce podającej dzieciom w szpitalu truciznę, tuż przed wejściem Niemców przeprowadzających akcję wysiedleńczą w warszawskim getcie (8 września 1942 roku) i 19-letniej pielęgniarce zabijającej nowo narodzone dziecko podczas akcji likwidacyjnej.

Czy jednak sposób odczytywania tych tekstów na lekcjach języka polskiego nie potwierdza tez sformułowanych przez Steinera czy Koziołek? Czy nie powinien nas zdumiewać kontrast między tymi strasznymi opowieściami, w których ból dziecka jest jednak wyjątkowym wyzwaniem dla indywidualnego systemu etycznego, wiary, a nawet kultury, a podporządkowaniem ich lektury, analizy i interpretacji namysłowi nad wzorcem postawy człowieka religijnego (Hiob), założeniami filozofii egzystencjalnej (Dżuma), deheroizacji (Zdążyć przed Panem Bogiem), etycznej prowokacji (opowiadania Borowskiego)? Czy tak rozumiane kształcenie literacko-kulturowe jednak przynajmniej w pewnym stopniu nie sprzyja obniżeniu wrażliwości, które zdiagnozował Steiner?4

Temu niepokojącemu zjawisku towarzyszy współcześnie dehumanizacja śmierci na skalę, która znacznie wykracza poza ramy wyznaczone jej choćby w tak trudnym do analizy tekście jak książka Hanny Krall. Wiąże się to z medialnym multiplikowaniem okrucieństwa i śmierci - także z udziałem dzieci i młodzieży. Jeden z rozmówców Katarzyny Boni i Wojciecha Tochmana, wynajmujący mieszkanie w Ramta, na północy Jordanii, pokazuje im na swoim telefonie niezwykły film:

Chcecie zobaczyć śmierć mojego syna? Jest na You-Tubie. (...)

Sięga po iPada, syn miał osiemnaście lat, ojciec wstukuje imię i nazwisko, i proszę: już oglądamy. Gdzie głowa, gdzie nogi, ciężko patrzeć, ciężko się zorientować, ale ojciec nalega, tu włosy, tu widać usta, dyszące ludzkie strzępy, tu były oczy. Bo korpus na szklanym ekranie wciąż jeszcze oddycha, a ten, który kręci komórką, wie, że nie ma dla chłopaka ratunku, czeka cierpliwie na ostatnie tchnienie. Trwa to może trzydzieści sekund, ranione ciało telepie się w ciszy, i my w ciszy czekamy, pół minuty konania, nie dłużej, Allah akbar, koniec filmu (Boni, Tochman 2014, 123).

Z takimi właśnie wstrząsającymi obrazami młodzi przebywający w obozach obcują na co dzień:

${ }^{4}$ Nie chodzi o to, by z tych ważnych dla kształcenia literackiego zagadnień zrezygnować, ale o to, by je dopełnić refleksją o egzystencjalnym dramacie, który jest za pomocą środków literackich wyrażany i przybliżany, i który nie tylko jest częścią kulturowej tradycji, ale i elementem naszej współczesności. Uzasadnione są też sugestie Krystyny Koziołek, która w książce Czas lektury proponuje, by w większym niż dotąd stopniu w edukacji polonistycznej uwzględniać opowieści ukazujące dobro (jako przeciwwagę dla bardzo licznie reprezentowanych w szkole opowieści o złu). 
Dzieci patrzyły na śmierć. I wciąż patrzą. W kieszeniach dorosłych pełno jest filmowego zabijania. Odtwarzają to sobie niemal bez przerwy, nic innego nie mają do roboty (Boni, Tochman 2014, 125).

Traumatyczne doświadczenia dzieci są nawet przedmiotem humanitarnych kampanii, jak tego dowodzi los dziewięcioletniej dziewczynki, której twarz „jest twarzą wielu międzynarodowych raportów, które krzywdę syryjskich dzieci układają w tabelki" (Boni, Tochman 2014, 128). Jej los, jak i cierpienie jej niespełna trzydziestoletniej matki, przywołuje z kolei na myśl biblijną opowieść o Hiobie i mit o Niobe. Najpierw w wieku sześciu lat dziewczynka została postrzelona przez snajpera (przed własnym domem, w dniu zawieszenia broni). Przeżyła, chociaż została częściowo sparaliżowana i skazana na życie z kulą w głowie. Gdy powoli dochodziła do zdrowia, pięć miesięcy później, uciekając przed kolejnym atakiem snajpera, złamała nogę. Kiedy Boni i Tochman rozmawiają z jej matką, ma ona dziewięć lat, śni koszmary, mówi niezrozumiałe słowa, boi się obcych. Okazuje się, że taka kumulacja cierpienia jest zaskakująca nawet dla dziennikarzy i organizacji humanitarnych, którzy są przecież oswojeni z ludzkimi tragediami. Ta jednak kombinacja okazuje się wyjątkowa, także medialnie - dlatego chętnie po nią sięgają. Przykład ten stanowi doskonałą ilustrację świadczącą o trafności diagnozy Steinera.

\section{Europa wartości (?)}

Niefikcjonalne opowieści o losie uchodźców zawierają oczywiście również inne możliwości ich wkomponowania w szkolną refleksję nad współczesnością, aksjologią i tradycją. W komentowanej książce Kontener proponuję na przykład przyjrzeć się opisom przestrzeni w obozach dla uchodźców i jej wpływowi na relacje rodzinne i społeczne. Można też wyodrębnić wiele motywów skłaniających uchodźców do opuszczenia swoich domów i do podjęcia ryzyka niebezpiecznej wyprawy do Europy w poszukiwaniu lepszego życia. Autorzy wiele miejsca poświęcają też rozpadowi więzi rodzinnych i przekomponowaniu ról mężczyzny, kobiety i dzieci, co w patriarchalnej kulturze Bliskiego Wschodu przyczynia się do pogłębienia i zaostrzenia wielu konfliktów.

W relacji Katarzyny Boni i Wojciecha Tochmana są też fragmenty opisujące obozową rzeczywistość uchodźców zadziwiająco przypominające „kamienny świat” Borowskiego czy łagrowy „inny świat” Gustawa Herlinga-Grudzińskiego:

Obozowe wytyczne: dorosła osoba je dwa tysiące sto kalorii dziennie. To pięćset sześćdziesiąt gramów jedzenia na osobę każdego dnia. Kobieta w ciąży dostaje trzysta kalorii więcej, karmiąca matka aż pięćset. Dzieci, które chodzą do szkoły, dostają ciasteczka. Pomimo tak wyliczonych kalorii uchodźcy narzekają na jakość wyżywienia. Są głodni (Boni, Tochman 2014, 67). 
Mimo odmiennych kontekstów historycznych i sytuacji ludzi żyjących w obozach pracy (nazistowskich i sowieckich) podczas II wojny światowej i tych skazanych na egzystencję w obozach dla uchodźców łączy całkowita zależność od świata zewnętrznego, a zwłaszcza od biurokratycznej machiny zarządzającej tymi miejscami, która reguluje w szczegółach sposób życia pojedynczego człowieka i całych grup. W przypadku obozu dla uchodźców celem jest zapewnienie im możliwości zaspokajania podstawowych potrzeb, a te określane są skrupulatnie przez odpowiednie organizacje, instytucje państwowe i międzynarodowe. Nie jest to ani „kamienny”, ani „łagrowy” świat, ale na pewno „inny”. Jego tymczasowe w założeniu struktury okazują się trwałe, a nagromadzenie wielu ludzi w ograniczonej przestrzeni, które ma dawać poczucie bezpieczeństwa, skazuje ich na funkcjonowanie w zonie i do minimum ogranicza jakąkolwiek możliwość decydowania o sobie. Innego znaczenia nabierają w tej rzeczywistości takie pojęcia, jak wolność, odpowiedzialność, solidarność itp.

Życie w obozie przedstawiane $\mathrm{w}$ reporterskich relacjach, zestawione z tekstami omawianymi w szkole, pozwala dostrzec, że „nieludzkie” światy nie są jedynie przypisane totalitaryzmom; są elementem otaczającej nas, jak najbardziej aktualnej, rzeczywistości. Dehumanizacja relacji międzyludzkich obserwowana w obozach dla uchodźców jest bardzo podobna do procesu dehumanizacji ukazanego w dziełach literackich omawianych z uczniami. Przykładem to ilustrującym może być emocjonalna wypowiedź Inżyniera Rolnika, 43-letniego ojca siedmiorga dzieci, uciekiniera z Syrii, właściciela trzech kontenerów w obozie Zaatari, który następująco charakteryzuje ów „inny” świat:

Syryjczycy to materialiści, mieliśmy ziemię, domy, dobrobyt i nagle straciliśmy wszystko, więc teraz, skoro już nam się udało przeżyć, musimy skombinować pieniądze, to nasze jedyne zadanie, każdy próbuje jakiś biznes ukręcić, a biznesy to, rzecz jasna, konflikty, o miejsce, o nieuczciwą konkurencję, masz taki sam towar jak ja, czemu go tak tanio sprzedajesz, ty gnoju, nie możesz dyktować tu cen, jak jeden dostanie w łeb, to cała rodzina staje za nim, cały klan, cała wieś, nawet nie pytają o powód, noże idą w ruch, sto pięćdziesiąt chłopa z jednej strony i sto pięćdziesiąt z drugiej, w biały dzień, nikt się nie wtrąca, w obozie nie ma policji, płoną namioty, latają kamienie, leje się męska krew, krzyczą kobiety, złorzeczą, wrzucają sąsiadom brudne pieluchy do cystern, aż wreszcie po dwóch dniach wszystkim się odechciewa, interweniują starsi, nikt się tu dobrze nie czuje, każdy marzy, żeby stąd uciec (Boni, Tochman 2014, 98-99).

Oczywiście książka Boni i Tochmana nie jest jedyną, po którą można sięgnąć, by sproblematyzować kwestie dla formacyjnego wymiaru edukacji polonistycznej tak ważne i odsłonić przed młodymi ludźmi głębię i skomplikowanie zagadnień współcześnie istotnych, także i tych związanych z kryzysem migracyjnym. W innych reporterskich opowieściach: Wielki przypływ Jarosława Mikołajewskiego, Lekarz z Lampedusy. Opowieść o cierpieniu i nadziei Pietro Bartolo i Lidii Tilotty, Miasto cierni. Największy obóz dla uchodźców Bena Rawlence’a, Na południe od Lampedusy. Podróże 
rozpaczy Stefano Libertiego czy Przez morze. Z Syryjczykami do Europy Wolfganga Bauera znajduje się bardzo wiele fragmentów pozwalających zrekonstruować „nieludzki” świat, który nie tylko znajduje się stosunkowo blisko Europy, ale który zmierza do niej, widząc w niej przestrzeń umożliwiającą rozpoczęcie życia na nowo. W światoodczuciu uchodźców dominuje wyobrażenie o Europie jako miejscu dostatnim, bezpiecznym, otwartym; nie ma w nim natomiast miejsca na fascynację jej kulturą, wartościami, osiągnięciami cywilizacyjnymi i historią, czyli sferą w edukacji powszechnej, nie tylko polskiej, szczególnie akcentowaną. To rozmijanie się dwóch sposobów myślenia o europejskości jest poważnym wyzwaniem.

Skutkiem rozpowszechnienia pierwszego z wyobrażeń jest to, że korzystają z niego przemytnicy, organizacje przestępcze (także terrorystyczne), handlarze ludźmi i ci wykorzystujący je do wzbogacenia się cudzym nieszczęściem, pragnieniem ucieczki czy wolą poprawienia swego życia. Skutkiem drugiego jest z kolei trudność w nawiązaniu dialogu z owym „innym” światem, przeobrażająca się w obojętność, niechęć, a nawet jawnie manifestowaną wrogość.

Tym cenniejsze są w przywołanych książkach przykłady postaw Europejczyków, którzy jednak tę granicę obojętności przekraczają w imię wartości uniwersalnych, dotąd uznawane za konstytutywne dla europejskiej tożsamości. Jednym z nich jest doktor Pietro Bartolo z Lampedusy udzielający pierwszej pomocy uchodźcom, którym udało się dotrzeć do wrót Europy, ale też orzekający często ich zgon. Dla Wojciecha Jagielskiego historia włoskiego lekarza ma jednak szersze, metaforyczne znaczenie, pozwalające umieścić ją w samym centrum refleksji nad wartościami, tożsamością europejską i człowieczeństwem:

Ale historia doktora Bartolo to także opowieść o nas samych i dzisiejszym świecie, pogubionym i przerażonym, a jeszcze tak niedawno sytym i pewnym swojego jutra. Jest to przypowieść o bezdennej i wciąż się pogłębiającej przepaści między bogatymi i nędzarzami, o współczesnej wędrówce ludów, niemożliwej do powstrzymania, będącej dla świata zachodniego wyzwaniem i próbą (Bartolo, Tilotta 2017, tylna okładka).

Ta rekomendacja słynnego polskiego reportażysty jest najlepszym dowodem na to, że opowieści o uchodźcach można, a nawet należy czytać w perspektywie aksjologicznej i egzystencjalnej. Są one bowiem dramatyczną kontynuacją narracji o europejskości, o wielkich ludzkich pytaniach i o człowieku. Pominięcie w tej narracji tego, co aktualne, niepokojące i trudne do opisania, może przyczynić się do utrwalenia stanu etycznej zapaści, o jakiej wspominał Steiner.

Wówczas pozostanie nam już tylko litość nad losem tych, których na przykład Krzysztof Miller uwiecznił na swoim zdjęciu z 10 kwietnia 1997 roku. Przedstawia ono trzech wycieńczonych z głodu chłopców, uchodźców z Rwandy, wypróżniających się do kartonu, w którym wcześniej znajdowały się produkty dostarczone do obozu dla uchodźców w Kongo w ramach 
pomocy humanitarnej zorganizowanej przez Unię Europejską. Komentarz fotoreportera do tej fotografii jest bardzo ostrą recenzją naszego wyobrażenia o europejskiej tożsamości i przekonania, że judeochrześcijańskie, greckie i rzymskie korzenie nadal są filarem europejskiego systemu etycznego:

Pod ścianą pokoju stoi dumny karton z dumnie wypasioną koroną gwiazd Unii Europejskiej. Pomoc humanitarna od Wysokiego Komisarza. Karton prawie pusty, więc służy za sracz tym, którzy leżą pod ścianami i zdychają z głodu.

Trójca bynajmniej nie święta. Nie Ojciec, Syn i Duch. Same duchy. Trójca dzieci na oko po siedem, dziesięć lat. Jedni z tych, którzy już nie żyją, choć dopiero umierają z głodu. Ale ja wiem, że nie przeżyją. Bo na cud się nie zanosi. (...) Jakaż paradoksalna symbolika każe im się wysrać na wtedy jeszcze pełną gębą bogatą i sytą Europę? Ich ciała są już jak ciała owadów (Miller 2013, 137).

Słowa Millera są prowokacyjne, ale, podobnie jak opowieść Boni i Tochmana, zmuszają do etycznego samookreślenia, i to wobec rzeczywistości poświadczającej rozpad wartości. Czy jednak takie nagłe i sugestywne wytrącenie człowieka, nawet młodego, z poczucia aksjologicznego bezpieczeństwa i z przekonania o ładzie i stabilności świata, w jakim sam żyje, nie jest dzisiaj warunkiem urzeczywistniania formacyjnego wymiaru kształcenia?

W innym komentarzu Millera do wspomnianego zdjęcia (w albumie o znamiennym tytule - Fotografie, które nie zmieniły świata) czytamy:

Do życia symetrycznego, czyli uporządkowanego, jesteśmy przyzwyczajeni. Bo wygodniej. Bo przewidywalniej. Ajak przewidywalniej, to bezpieczniej. Dla Nich, tych na zdjęciu, nic nie jest już bezpieczne, symetryczne. Śmierć jest niesymetryczna. (...) Niesymetryczna jest też godność tych dzieciaków, które mają siłę wstać z barłogu i wypróżnić się do kartonu z dumnymi gwiazdami Unii Europejskiej.

To dla mnie heroizm (Miller 2017, 56).

Należy zauważyć, że bardzo krytyczna refleksja nad stosunkiem Zachodu do problemu uchodźców wyrażona jest jednak w tym przypadku językiem odwołującym się do wartości, których rozumienie ukształtowane zostało w kręgu kultury śródziemnomorskiej. Miller pisze o heroizmie trójki dzieci, daje wyraz swojej wrażliwości na cierpienie, którego jest świadkiem, a którego nie może przerwać, jak również odwołuje się do pojęcia godności. Opisuje antychrześcijańską rzeczywistość przez pryzmat chrześcijańskich wartości. Może więc w edukacji polonistycznej oprócz utrwalonego w dydaktycznej tradycji przybliżania kulturowego dziedzictwa kultury europejskiej należałoby spojrzeć na współczesny świat za pośrednictwem wartości dla tego dziedzictwa reprezentatywnych, także po to, by uwrażliwić na zło i ograniczyć przynajmniej w pewnym stopniu obniżanie progu wrażliwości na przemoc i cierpienie innych.

Trudno oczekiwać, by taka postawa stała się powszechna; troska o to jest jednak potrzebna, by refleksja nad wartościami w szkole miała w ogóle jakiś sens. Istotę tak rozumianej formacji trafnie oddają słowa dedykacji, którymi Jarosław Mikołajewski otwiera, i podziękowania, którymi kończy swoją książkę pt. Terremoto: 
Dla Luki

i Włochów, którzy mając góry,

nie zapominają o morzu,

ratując innych,

ocalają siebie

i nas

(Mikołajewski 2017, 5)

Pragnę podziękować (...) Włochom - za to, że wśród nieszczęść, które spadają na nich spod ziemi, z nieba, z powietrza, wody i ognia, mają siłę pamiętać, że są najpierw ludźmi, a dopiero potem Włochami (Mikołajewski 2017, 135).

\section{Bibliografia:}

Bauer Wolfgang, 2016, Przez morze. Z Syryjczykami do Europy, Kalinowska E. (przeł.), Wołowiec.

Bauman Zygmunt, 2016, Obcy u naszych drzwi, Mincer W. (przeł.), Warszawa.

Bobkowski Andrzej, 2003, Szkice piórkiem, Warszawa.

Boni Katarzyna, Tochman Wojciech, 2014, Kontener, Warszawa.

Chrząstowska Bożena, 2009, Konteksty aksjologiczne, w: Przedmiot, podmiot, proces. Szkice z metodyki kształcenia polonistycznego, Poznań, s. 145-162.

Kapuściński Ryszard, 2006, Ten Inny, Kraków.

Kłakówna Zofia Agnieszka, 2017, Język polski. Wykłady z metodyki. Akademicki podręcznik myślenia o zawodzie szkolnego polonisty, Kraków.

Koziołek Krystyna, 2017, Czas lektury, Katowice.

Liberti Stefano, 2013, Na południe od Lampedusy, Wyrembelski W. (przeł.), Wołowiec.

Mikołajewski Jarosław, 2017, Niewierzacy praktykujacy, „Gazeta Wyborcza”, 14.06.2017, http://wyborcza.pl/7,75968,21957829, niewierzacy-praktykujacy. html (dostęp 10.09.2017).

Mikołajewski Jarosław, 2017, Terremoto, Warszawa.

Mikołajewski Jarosław, 2015, Wielki przypływ, Warszawa.

Szwecja czyta. Polska czyta, 2015, Tubylewicz K. i Diduszko-Zyglewska A. (red.), Warszawa.

Miller Krzysztof, 2013, 13 wojen i jedna, Kraków.

Miller Krzysztof, 2017, Fotografie, które nie zmieniły świata, Warszawa.

Rawlence Ben, 2017, Miasto cierni. Największy obóz dla uchodźców, Kowalski S. (przeł.), Wołowiec.

Steiner George, 1993, W zamku Sinobrodego. Kilka uwag w kwestii przedefiniowania kultury, Kubińska O. (przeł.), Gdańsk.

Uryga Zenon, 1996, Godziny polskiego. Z zagadnień kształcenia literackiego, Warszawa-Kraków. 


\section{O Autorze:}

Krzysztof Koc - doktor nauk humanistycznych w zakresie literaturoznawstwa, adiunkt w Pracowni Innowacji Dydaktycznych UAM w Poznaniu; nauczyciel języka polskiego w gimnazjum i liceum; autor książki Czytanie świata. Reportaże Ryszarda Kapuścińskiego $w$ edukacji polonistycznej (Poznań 2007) i współautor podręcznika akademickiego dydaktyki kształcenia polonistycznego Innowacje i metody. W kręgu teorii i praktyki, pod red. M. Kwiatkowskiej-Ratajczak (Poznań 2011), publikował m.in. w „Polonistyce”. Obecnie pracuje nad książką poświęconą metodyce koncepcyjnej. 